Supplement of Geosci. Commun., 3, 99-108, 2020

https://doi.org/10.5194/gc-3-99-2020-supplement

(C) Author(s) 2020. This work is distributed under

the Creative Commons Attribution 4.0 License.

(c) (1)
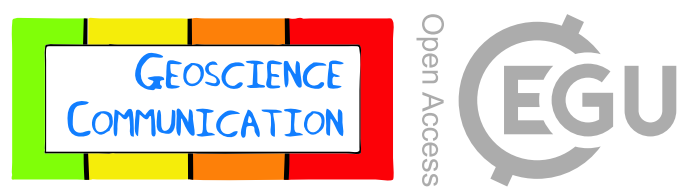

Supplement of

\title{
Ozone measurement practice in the laboratory using Schönbein's method
}

Ignacio Arturo Ramirez-Gonzalez et al.

Correspondence to: Juan Antonio Añel (j.anhel@uvigo.es)

The copyright of individual parts of the supplement might differ from the CC BY 4.0 License. 


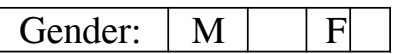

\begin{tabular}{l|l|l|} 
Age: & & Grade:
\end{tabular}

1. Do you know what climate change is?
\begin{tabular}{|l|l|}
\hline Yes & \\
\hline
\end{tabular}
\begin{tabular}{|l|l|}
\hline No & \\
\hline
\end{tabular}

2. Do you know how to differentiate between the problem of the ozone layer and the problem of climate change?

\begin{tabular}{|l|l|l|}
\hline Yes & No \\
\hline
\end{tabular}

3. Do you think you have enough information about it?

\begin{tabular}{|l|l|l|}
\hline Yes & No & \\
\hline
\end{tabular}

4. Do you think it is possible to solve it?
\begin{tabular}{|l|l|l|l}
\hline Yes & \\
\hline
\end{tabular}
\begin{tabular}{|l|l|}
\hline No & \\
\hline
\end{tabular}

5. Do you think you are suffering the impacts of climate change already?
Yes
\begin{tabular}{|l|l|}
\hline No & \\
\hline
\end{tabular}

6. Do you think its effects will be worse in a few years?
Yes
\begin{tabular}{|l|l|}
\hline No & \\
\hline
\end{tabular}

7. Rate the problem severity from 0 to 10 (Being a 0 nothing and 10 extreme severity):

Rating:

8. Do you think your actions have consequences for climate change?
Yes
\begin{tabular}{|l|l|}
\hline No & \\
\hline
\end{tabular}

9. Would you change your habits to curb climate change?
\begin{tabular}{|l|l|}
\hline Yes & \\
\hline
\end{tabular}
\begin{tabular}{|l|l|}
\hline No & \\
\hline
\end{tabular}

10. Have you ever worried about the problems or air quality at your locality?
Yes
\begin{tabular}{|l|l|l|l}
\hline No & \\
\hline
\end{tabular}

11. Do you think we should invest more in climate change research?
Yes
\begin{tabular}{|l|l|l|l|l|l|}
\hline No & \\
\hline
\end{tabular}

12. Should more government action be taken to curb climate change?

\begin{tabular}{|l|l|l|}
\hline Yes & No \\
\hline
\end{tabular}

13. Have you heard of the United Nations Intergovernmental Panel on Climate Change?
Yes
No

14. Do you know their activities?
Yes
\begin{tabular}{|l|l|l|l|l}
\hline No & \\
\hline
\end{tabular}

15. Do you consider that this content is well enough included in the teaching curriculum?

\begin{tabular}{|l|l|l|}
\hline Yes & \\
\hline
\end{tabular}

16. Do the teachers tell you about these subjects during the classes?
Yes
No

17. Are there other activities in your highschool that let you learn about this topic?
Yes
No

18. Would you like to know more about this topic?
Yes
\begin{tabular}{|l|l|}
\hline No & \\
\hline
\end{tabular}

19. Have you commented or discussed climate change with your family?

\begin{tabular}{|l|l|l|}
\hline Yes & No \\
\hline
\end{tabular}

